\title{
Racial Intermarriage in the Americas
}

\author{
Edward Telles, ${ }^{a}$ Albert Esteve ${ }^{b}$
}

a) University of California, Santa Barbara; b) Centre d'Estudis Demogràfics, Universitat Autònoma de Barcelona

Abstract: We compare intermarriage in Brazil, Cuba, and the United States among the black, white, and mixed-race population using log-linear models with data from newly available anonymized and harmonized individual census microdata for the 2000 round of censuses. We find that black-white intermarriage is 105 times as likely in Brazil and 28 times as likely in Cuba compared to the United States; that Brazilian mulatos are four times as likely to marry whites than blacks, but Cuban mulatos are equally likely to marry whites and blacks; and negative educational gradients for black-white intermarriage for Cuba and Brazil but nonexistent or positive gradients in the United States. We propose a theory of intergenerational mixture and intermarriage and discuss implications for the role of preferences versus structure, universalism and education, and mulato escape-hatch theory.

Keywords: intermarriage; Brazil; Cuba; mulato escape hatch

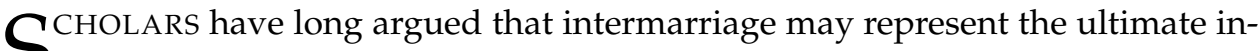
$\mathcal{S}$ dicator of ethnoracial boundary crossing (Park and Burgess 1921; Gordon 1964; Rodriguez-Garcia 2015). Analysts of intermarriage have drawn attention to the particular rigidity of the black-white boundary and to the positive relation between intermarriage and education (Kalmijn 1993; Qian and Lichter 2007; Fryer 2007). The former finding follows Robert Park's (1928) observation that race or physical rather than cultural differences are the major impediment to intermarriage or assimilation. Positive educational gradients are consistent with the idea that more educated persons have more individualistic and universalistic attitudes and they are less attached to family and community of origin and thus more likely than less educated persons to marry members of outgroups. These findings, however, are based on evidence from the United States, where African Americans are far less likely to

Citation: Telles, Edward, and Albert Esteve. 2019. "Racial Intermarriage in the Americas." Sociological Science 6: 293-320.

Received: January 7, 2019

Accepted: February 5, 2019

Published: April 23, 2019

Editor(s): Jesper Sørensen, Gabriel Rossman

Dol: $10.15195 / \mathrm{v} 6 . \mathrm{a} 12$

Copyright: (C) 2019 The Author(s). This open-access article has been published under a Creative Commons Attribution License, which allows unrestricted use, distribution and reproduction, in any form, as long as the original author and source have been credited. (C) (i) marry whites ${ }^{1}$ than are Hispanics, Asian Americans, or American Indians (Kalmijn 1993; Jacobs and Labov 2002; Qian and Lichter 2007; Fu 2010; Fryer 2007 ), and in the case of educational gradients, findings are based on several ethnoracial groups in the United States and various European countries (Kalmijn 2012).

However, we argue that the rigidity of the black-white boundary and positive educational gradients that have been widely documented in the U.S. sociological literature are context specific and cannot be generalized to other societies. We examine Brazil and Cuba, where the populations of enslaved Africans were more than 10 and two times larger, respectively, than those brought to the United States (Eltis et al. 1999; Eltis 2017; de la Fuente and Andrews 2018) and where patterns and levels of intermarriage may be quite distinct (Telles 2004; Fernandez 2010; Osuji 2013). We know very little about racial intermarriage in those countries, except for descriptive comparisons showing greater racial intermarriage for Brazil (Telles 2004; Costa Ribeiro and do Valle Silva 2009; Gullickson and Torche 2014) and suggesting higher rates for Cuba than in the United States (Catasus 1989; Rodriguez Ruiz 2004; 
Fernandez 2010). There are no systematic intercountry comparisons, and we know nothing about educational gradients.

By comparing countries with large black and white populations and decentering the analysis of intermarriage away from the United States, we go beyond the single-country focus of previous work on intermarriage, potentially leveraging national differences in laws, policies, narratives, and demographic structures in understanding the extent of white-black racial boundaries (Telles and Paschel 2014). Histories of slavery and high levels of antiblack animus in all three countries (de la Fuente 2001; Telles 2004) suggest low levels of black-white intermarriage generally, as theories of intermarriage predict (Davis 1941; Kalmijn 1998). However, the Brazilian and Cuban cases featured national narratives about race mixture (mestizaje) and lacked antimiscegenation laws, which suggest higher levels of intermarriage than in the United States. Also, levels of racial inequality create structures that affect social boundaries and opportunities for interracial interaction, predicting much greater intermarriage in Cuba than in Brazil, with the United States being in-between (though mediated by its higher levels of residential segregation).

In this study, we examine black-white marriages in Brazil, Cuba, and the United States using traditional definitions of the black category. We also explore intermarriage in Brazil and Cuba for the intermediate and large racial category of mulatos (mixed-race persons with African or indigenous and European ancestry; also known as pardos in Brazil, but henceforth, we use mulatos for comparative purposes) ${ }^{2}$ compared with whites and blacks. Finally, we investigate educational gradients of intermarriage on the black-to-white continuum in the three countries to examine the relation between education and racial intermarriage. The recent availability of anonymized and harmonized individual census microdata for the 2000 round of censuses of Brazil, Cuba, and the United States allows for a comparative analysis of racial intermarriage in the three countries. We use log-linear techniques, which effectively control for the size of the population by race, sex, educational attainment, type of union (marriage vs. cohabitation), and region (i.e., states in Brazil and the United States and provinces in Cuba).

\section{Background}

\section{Theory}

Intermarriage has many useful properties for understanding the extent of rigidity or permeability of social boundaries in a given society (Park and Burgess 1921; Gordon 1964; Rodriguez Garcia 2015). According to Gordon's (1964) assimilation theory, intermarriage represents the undermining of the ultimate barrier to full social acceptance of excluded or formerly excluded outgroups (Qian and Lichter 2007). Its occurrence probably signifies the most intimate of social interactions and the breakdown of rigid social boundaries. At the individual or couple level, intermarriage suggests that intermarried partners accept each other as social equals and represent high levels of social tolerance or low levels of social distance (Gordon 1964; Kalmijn 1998; Qian and Lichter 2007). Given that marriage involves a 
long-term commitment, particularly in formal unions, intermarriage thus signals particularly strong levels of racial tolerance.

At the societal level, intermarriage is measurable for a large segment of the population (i.e., the married population), allowing for an examination of the degree or pervasiveness of racial tolerance or openness or the degree of rigidity of racial boundaries (Barth 1969; Wimmer 2008). By calculating intermarriage rates, analysts may then examine changes over time or differences across nations, social strata, or ethnoracial groups. We interpret differences in intermarriage across nations or across educational segments as reflecting the relative rigidity of racial boundaries across countries or social strata (Heaton and Mitchell 2012).

Davis (1941) posited that more rigid stratification systems produce more stringent endogamy. The more segmented or stratified the context, whether in economic, social, ethnic, racial, or religious terms, the less likely there are to be mixed unions between individuals who represent polarized groups or socially distinct categories (Davis 1941; Kalmijn 1998; Rodriguez Garcia 2015). Opportunities for persons belonging to distinct racial categories to meet depend on structural factors such as class distance and residential segregation (Kalmijn 1998).

In the Cuban case, racial educational inequality is relatively minor compared to Brazil and the United States such that opportunities for interaction would seem to be the greatest of all three countries. Because racial inequality in socialist $\mathrm{Cuba}$ is particularly low (de la Fuente 2001; Sawyer 2005), blacks and whites, who are particularly likely to share similar socioeconomic levels, would have greater chances of meeting each other, and similar class levels would likely lead to greater shared resources, including more common cultural capital. At the other extreme, in highly unequal Brazil, the upper and upper-middle classes are almost entirely white, whereas the poor are disproportionately nonwhite (Telles 2004), thus creating distinct class opportunities for persons of different races to meet. Interracial interaction is likely to be least common among the most educated and among the upper-middle class. The United States is intermediate, although high levels of residential segregation diminish interaction opportunities. In Brazil, residential segregation is relatively moderate, and labor markets are less segregated than in the United States (Telles 2004).

Kalmijn $(1998,2012)$ theorizes that in addition to structural factors, intermarriage patterns also arise from culture, including preferences, norms, and values. In particular, individuals hold preferences for certain characteristics in potential partners and are influenced by third parties, particularly social groups or institutions such as family, church, and state. Families continue to exert pressures on partner choice in Brazil (Osuji 2013; Hordge-Freeman 2015), Cuba (Fernandez 2010), and the United States (Osuji 2013). In the United States, 17 states had antimiscegenation laws as late as 1967 (Qian and Lichter 2007; Fryer 2007). By contrast, the Brazilian and Cuban states have never sanctioned miscegenation or intermarriage (de la Fuente 2001; Telles 2004). To the contrary, Brazil and Cuba have featured elite-led race mixture (mestizaje) narratives since the early twentieth century (Skidmore 1974; de la Fuente 2001; Telles and Garcia 2013). Notably, unlike most Latin American countries with mestizaje narratives, Brazil and Cuba are exceptional for celebrating African contributions as central to the nation (Skidmore 1974; de la Fuente 2001). 
Swidler (1986) theorized that national narratives or myths create cultural repertoires or "common sense" on which individuals draw and that, in turn, pattern social actions. We similarly argue that mestizaje (race mixture) narratives in Brazil and Cuba, which continue to be widely accepted (Telles and Garcia 2013), may become norms or scripts that promote intermarriage (Telles 2004). Brazilians and Cubans may thus be more open to racial intermarriage than North Americans because of norms derived from national mestizaje ideologies. Also, cultural mestizaje or syncretism, which can also be found in music, food, religion, and the "lived experiences" of Latin Americans (Wade 2005), further reinforces a greater tolerance for mixture. Brazil's race mixture ideologies include the idea of racial democracy, which contends that there is little or no racial democracy in that country, and the dominance of that ideology probably forestalled antiracist policies in that country until only the past two decades, when it instituted race-based affirmative action (Telles 2004).

We borrow from Kalmijn's (2012) idea that the occurrence and pervasiveness of intermarriage may also influence social norms about its acceptability in future generations. In Brazil and Cuba, actual mixture probably began during colonization, as men greatly outnumbered women among Spanish and Portuguese immigrants, and thus, men often sought out nonwhite females as sexual mates, concubines, and partners (Wade 1997; de la Fuente 2001; Telles 2004), spawning, consensually and forcibly, a mixed-race population. This compares to the more balanced sex ratio among whites in the U.S. colonies, where families predominated among colonial settlers and European immigrants of all social classes, through most of U.S. history. Intermarriage, or biological mixture in general, also leads to a larger mixed population in the next generation, which itself is presumably more likely to intermarry, as intermarriage or mixture comingles relatives, friends, and other persons in the social networks of intermarried partners, creating more interracial ties throughout these societal networks and changing norms about interracial marriage. Such normative and sociodemographic changes make intermarriage more likely to be accepted and increasingly common in subsequent generations.

Some scholars (Davis 1941; Degler 1971) have also claimed that Portugal and Spain have greater cultural tolerance of nonwhites because of seven centuries of experience with the Moorish presence in the Iberian Peninsula (711 to 1492), but this is consistent with the theory that intergenerational mixture, which is strongly suggested by genetic evidence (Adams et al. 2008), leads to growing tolerance in future generations.

\section{Educational Gradients}

Status homogamy refers to the extent to which spouses seek out partners similar to themselves on the basis of socioeconomic, racial, and cultural characteristics (Kalmijn 1991). Empirical research from the United States shows that education is a prime criterion for choosing a spouse because it reflects both potential income and cultural dimensions (Blau and Duncan 1967; Kalmijn 1991). Findings for the United States show that black-white intermarriage increases with education, particularly for black men, though racial intermarriage is quite limited at all educational levels 
(Kalmijn 1991; Qian and Lichter 2007). Based on such U.S. findings, Kalmijn (1998) theorizes that educational gradients are positive in interracial marriage because more educated persons have more individualistic and universalistic attitudes and they are less attached to family and community of origin, thus making them more tolerant and likely to intermarry. However, in Brazil, where levels of social inequality are among the highest in the world, interracial mixture, like intermarriage today, is likely to have been especially common in lower social strata, where persons of various hues and phenotypes have coexisted in large numbers and thus have had greater opportunities to interact (Telles 2004). Based on descriptive evidence for intermarriage and drawing on our intergenerational theory of mixture and intermarriage, where mixture in Brazil (and Cuba, historically) is concentrated in lower strata, educational gradients may be opposite in Brazil and Cuba. Because interracial pairings could become familiar and thus accepted or tolerated among lower-status individuals, such class differences in homogamy would be transmitted intergenerationally. This could possibly overwhelm potential effects of greater universalism among the higher educated.

A negative educational gradient is consistent with the positive relation between whiteness and high social status in Brazil and other Latin American countries (Flores and Telles 2012; Marteleto 2012). Also, whether universalism is greater among the most educated in Brazil and Cuba is unclear, although public opinion surveys in Brazil suggest that racial tolerance is similar for all persons regardless of race and class (Bailey 2009; Telles and Bailey 2013). Finally, low levels of racial inequality in Cuba would imply that racial and class differences in individualism and tolerance, which are theorized to lead to greater interracial intermarriage among higher-status individuals, are relatively small, and thus educational gradients, whether positive or negative, would be small.

In Brazil, a common argument was that racial discrimination could be reduced to class discrimination; thus, race was merely an epiphenomenon of class (Fernandes 1965). According to this argument, barriers to interracial marriage are merely class based such that reductions in racial inequality would lead to higher levels of intermarriage, even suggesting that interracial marriage would be random or near random at each educational level once factors such as geographic differences are controlled. Such class-not-race thinking in Brazil was largely the result of Marxistinspired theories popular in Brazilian academia, which were consistent with racial democracy ideas that race was unimportant in Brazil (Hasenbalg 1985; Telles 2004). Although such ideas have virtually disappeared among serious analysts in Brazil, research shows that racial inequality is due to both class origins and race (do Valle Silva 1985; Telles, Flores, and Urrea-Giraldo 2015) and blacks or dark-skinned individuals often perceive discrimination as being based on both class and race (Dixon 2015).

Indeed, similar class arguments about racial inequality have become the pillar of Cuba's state efforts since the 1960s, to end racial inequality and discrimination, thus setting up a natural experiment about whether its low levels of racial inequality have led to near random rates of intermarriage. The Cuban government expected that the eradication of structural inequalities and several decades of generational replacement, bolstered by a socialist antiracist education (Fernandez 2010), would 
end or greatly diminish the previous and deep-seated racist attitudes of Cuban class distinctions and eliminate racism (Sawyer 2005). Theoretically, Cuba's low levels of racial inequality could thus undermine the structural bases of racial homogamy (though not necessarily changing racial preferences). Researchers have noted that although economic equality has been attained, leaders have been inattentive to Cuba's deep racism prior to the revolution and have thus ignored the persistent antiblack attitudes (de la Fuente 2001; Sawyer 2005), including the victimization of interracial couples as targets of racist commentary (Fernandez 2010) ${ }^{3}$.

Unfortunately, there has been almost no analysis of racial intermarriage in contemporary Cuba except for some descriptive data from the 1981 census (Catasus 1989) and at least one unrepresentative local survey (Rodriguez Ruiz 2004; Fernandez 2010), although a pioneering ethnography was recently produced for interracial marriage in Cuba (Fernandez 2010). Fernandez (2010) examines "why contemporary interracial couples are the targets of racist commentary and social disapproval if the nation has such a long tradition of mestizaje and decades of socialist equality." There has been no systematic quantitative analysis of racial intermarriage largely because national censuses of Cuba have not been available in a format for such analysis.

\section{The Position of Mulato Persons}

The historic use of a mulato category in Brazil and Cuba and large numbers of persons who are classified as such reveal an important distinction with the United States, ${ }^{4}$ suggesting a tripartite racial system in the Latin American countries along the black-to-white continuum compared with a bipolar system in the United States (Telles 2004; Bailey 2009). Mulato persons in Brazil and Cuba may serve as a buffer between blacks and whites in intermarriage because their status, whether real or perceived, is intermediary. Regarding structure, blacks tend to be at the bottom and whites are at the top, whereas mulato persons are somewhere in-between, the exact place depending on the society. In terms of preferences, there may be an affinity effect in which mulato persons feel close to whiteness and blackness because of shared background with both and presumably greater social interaction with both in their families and communities, or they may have a preference for one or the other. Whitening theory would suggest that mulatos indeed prefer whites (Skidmore 1974; Telles 2004; Schwartzman 2007), though that does not account for reciprocal attitudes from whites. We thus examine the tripartite black-white-mulato system of Brazil and Cuba, where the intermediate category represents a large population segment and adds to the complex demographic and social dynamics inherent in this system. For intermarriage, we thus ask whether mulatos are equally likely to marry blacks as whites, or are they more likely to marry whites or marry blacks?

White, mulato, and black represent ordered racial status categories, but the exact position of the intermediate mulato category may vary and be disputed. Degler's (1971) mulato escape hatch theory, based on ethnographic studies of Brazil by Marvin Harris and others, holds that Brazil is different from the United States because mixed-race persons may become classified as or accepted as white or near white with upward mobility, therefore escaping the stigma and discrimination associated 
with blackness (e.g., Harris et al. 1993). However, statistical studies using large, random data sets have found that mulato persons in Brazil are much closer to blacks in socioeconomic position (Hasenbalg 1985) or vertical relations more generally (Telles 2004). The black movement has used this finding in efforts to mobilize blacks (pretos) and mulato persons around a single "black" category (henceforth, we use "black" when referring to the negro [i.e., combined black and pardo] category) (Hanchard 1994; Telles 2004), arguing that the primary racial boundary is between white and "black" and that there is little difference in how society treats blacks and mulatos. Moreover, the Brazilian government and academics generally argue for a unified "black" category, following a similar logic. However, it is not clear whether the mulato-black distinctions are important to intermarriage, an indicator of horizontal relations.

The mulato escape hatch theory would predict that mulatos would be about equally likely to marry whites as blacks, but the more widely accepted social position theory suggests that because blacks and mulatos are structurally similar, and thus opportunities for interacting are greater for meeting each other than whites, mulatos would be more likely to marry blacks than whites. The former is consistent with descriptive evidence for Brazil (do Valle Silva 1987; Telles 2004), but that does not consider intervening effects such as group size. However, preferences may be a different matter. Whites may be more willing to marry brown-skinned people and brown-skinned people may be more likely to marry whites than either group is to marry blacks because of the low social status of blacks. Moreover, Cuba and Brazil may be different. We simply do not know much about white or mulato cognitive responses to blacks in either country, but we suspect that antiblack animus comes from both whites and mulatos, as mulatos may consider themselves as closer to the white ideal and may distance themselves from blacks. Unfortunately, studies of mulatos separate from blacks are rare. The common aggregation of blacks and mulato persons into a single "black" category has had the effect of inhibiting scholarly explorations of mulatos and their interactions with whites and blacks. ${ }^{5}$

Unfortunately, we do not test a mulato escape hatch theory for the United States for reasons of data availability and comparability. A mulato category or categories existed in the U.S. census from 1870 to 1920, but its disappearance was related to the growing prevalence of legal segregation, antimiscegenation laws, and the institution of the one-drop rule, whereby black-white persons were relegated to the black category (Nobles 2000; Davis 2001). Mulato is rarely used in popular discourse in the United States, although a biracial movement has since the 1990s sought to promote the use of a mixed-race category in the census (Nobles 2000) comprised of persons who may variously identify as mulato, mixed, or biracial. Nevertheless, African Americans of light skin color, which might serve as a proxy for mulatos in the United States, tend to have a social status that is between whites and darkskinned African Americans, and light-skinned African American women are more valued in the dating and marriage market (Hughes and Hertel 1990; Hunter 2005; Hamilton, Goldsmith, and Darity 2009). Keels and Harris (2014) find that lightskinned African Americans are more likely to date interracially than medium- and dark-skinned counterparts, and as far as we know, there has been no analysis of racial intermarriage regarding African Americans by skin tone or the mixed-race 
population in the United States. The lack of studies on interracial marriage for mixed-race persons is probably because mixed-race categories and skin color are not included in the census or other large-scale data sets, which are generally needed to analyze cases of intermarriage along the black-white continuum.

\section{Selection of Brazil, Cuba, and the United States}

Brazil, Cuba, and the United States were, in that order, among the largest destinations of enslaved Africans in the Americas (Eltis 2017), but their postslavery histories vary widely. Summing the black and brown population, Brazil today has the largest number, in absolute and proportional terms, whereas Cuba has the second largest number proportionately but the smallest in absolute terms. The United States is the second largest in absolute terms but the smallest proportionately, yet it has become the paradigmatic case in the study of race relations. According to the 2010 Brazilian census and the 2002 Cuban census, the population considered Afro-descendant (preto and pardo in Brazil; negro and mulato in Cuba) comprised 51 percent of the Brazilian population in 2010, 35 percent of the Cuban population in 2002, and 12 percent of the United States in 2010 (Telles and the Project on Ethnicity and Race in Latin America 2014). Asian Americans and Hispanics comprise about 20 percent (and growing) of the U.S. population, but nonblack minorities are very small in Brazil and Cuba (Telles and the Project of Ethinicity and Race in Latin America 2014). The largest group is Asians in Brazil, who comprise less than 1 percent of the national population. Unlike the United States, where presumably persons with any black blood are considered black (Davis 2001), in Brazil, and possibly in Cuba, many whites might also have African or indigenous ancestors; these are countries where race is determined mostly by appearance rather than ancestry (Telles 2004).

The three nations have quite distinct racial stratification systems and racial histories and politics. For example, educational differences by race are particularly great in Brazil and almost nonexistent in Cuba, with the United States being in-between, and there are strong race mixture ideologies in Brazil and Cuba but not in the United States. Also, racial politics vary widely among the three countries. Most notably, the United States ended segregation and hypodescent and antimiscegenation laws and has instituted civil rights laws and affirmative action policies since the 1960s (Davis 2001), Cuba has had a socialist government that proclaimed victory against racial inequality and has been inattentive to race issues since the 1960s (de la Fuente 2001), and Brazil was considered a racial democracy from the 1930s until fairly recently, when it instituted affirmative action in higher education in the early 2000s and there was a widespread recognition of racism for the first time (Telles 2004). However, racial prejudices and discrimination persist in all three societies.

\section{Data}

Census microdata samples harmonized by the Integrated Public Use of Microdata Series International (IPUMS-I) project (Minnesota Population Center 2017) provided the data for this research. Data were selected from the following samples of 
individuals organized into households: Brazil 2000 (6 percent), United States 2000 (5 percent), and Cuba 2002 (10 percent). All coresiding couples in which women were 25 to 34 years old at the time of the census were selected. Coresiding couples were identified on the basis of the spouse location variable (SPLOC). SPLOC is an IPUMS-constructed variable, mainly based on "relationship to the household head," that identifies the position (if present) of the married or unmarried partner within the household. Alternative age or sex specifications yielded similar results. The analysis was restricted to young couples to minimize biases due to union dissolution, remarriage, and educational upgrades after marriage (Schwartz and Mare 2012) and to examine couples formed in the same period. Furthermore, at these ages, we maximize the number of women in unions and minimize the differences across countries. To illustrate, the percentage of women in unions at the age of 34 was 80 percent in Brazil, 74 percent in Cuba, and 78 percent in the United States.

The main variable of interest is race of the spouses. ${ }^{6}$ We use three racial categories: white, black, and mulato. In Brazil and the United States, race was selfreported by the respondent given a set of predefined categories. By contrast, in Cuba, the skin color of the respondent was enumerated by the interviewer given a set of predefined categories. In Brazil, the question on race included the following categories: branco (white), preto (black), amarelo (yellow), pardo (brown), and indigena (indigenous). In Cuba, the question referred to skin color, and the options were blanco (white), negro (black), or mestizo o mulato (mixed). We primarily use the term mulato to refer to pardos in Brazil and mestizos and mulatos in Cuba.

For the United States, we focus on the white and black racial categories. Following standard procedures in the literature (e.g., Qian and Lichter 2007), persons of Hispanic ancestry are excluded from both categories. There is no mulato category in the United States comparable to the one in Brazil and Cuba. Mulatos in the United States could have potentially been identified through considering those who checked the white and black categories in the census form. However, these individuals only represent 0.26 percent of the sample.

The black category in Brazil and Cuba includes only pretos and negros, respectively, whereas in the United States, it includes all persons of African origin. For the sake of comparability, we run models merging mulatos with blacks in Brazil and Cuba (results are available from the authors). Because of the much larger size of the mulato population relative to the black population and the distinct marriage patterns for blacks and mulatos, a combined nonwhite (black-mulato) category would largely reflect mulato patterns and conceal distinct black patterns. Thus, we decided to treat them separately.

We recognize that racial classification tends to be especially fluid in Brazil and probably Cuba, where racial self-identification may respond to the particular context of the census survey or be relational to other family members, including the spouse (Telles 2004). There are certainly other ways to measure race (Roth 2017), but censuses have become official data about race, and self-identity has become the international standard for racial classification (Loveman 2014). Also, the Brazilian census, which asks about color, is closely correlated with interviewer racial classification (Telles and the Project of Ethnicity and Race in Latin America 2014), and because the Cuban census similarly asks about color but there is no study 
to verify this, we expect similar findings. Finally, there simply are no other data that permit log-linear analysis of intermarriage in Cuba.

In addition to race, we classified couples according to educational attainment, type of union, and region of residence, which are used as control variables. We have coded educational attainment into four categories: low, medium low, medium high, and high. These categories are delimited by different educational thresholds depending on the country: 0 to 3,4 to 7,8 to 11 , and 12 or more years of schooling in Brazil; primary, lower secondary, secondary completed, and college completed in Cuba; and no high school diploma, high school diploma, some college, and college completed in the United States. Alternative classifications of educational attainment yielded very similar results. Had we used the same thresholds throughout, some categories would have had extremely few cases. For instance, more than 60 percent of women aged 25 to 34 had at least some college education in the United States 2000, but only 8.3 percent had this in Brazil 2000. Hence, for the United States, we distinguished between some college and college, whereas in Brazil, these two categories were combined.

As control variables, we included type of union and region. We distinguish between married and cohabiting couples because the extent of cohabitation differs significantly between Brazil and Cuba on the one hand and the United States on the other (Esteve and Lesthaeghe 2016). In addition, there is evidence that shows that intermarriage is more common among cohabiting unions than in married ones (Esteve, Lesthaeghe, and López-Gay 2012). Indeed, some authors argue that the rise in cohabitation in the United States has contributed to increased intermarriage (Kalmijn 1998; Qian and Lichter 2007).

Cohabiting unions were identified differently in the three countries. The Brazilian census had a direct question on union status that, combined with the classical census question on marital (legal) status, made it possible to differentiate between married and cohabiting couples. In Cuba, the question on marital status included an item for cohabiting unions (unidos). In the United States, unmarried coresiding partners were identified as cohabitors.

Finally, we consider region of residence to account for the racial composition across regions. Ignoring this may lead to overestimation of the distance between racial groups (Harris and Ono 2005). We break down the analysis into 27 states in Brazil, 51 states in the United States, and 15 provinces in Cuba. To illustrate the variation among regions, in Brazil 2000, for example, the percentage of black women aged 25 to 34 ranged from 2.5 percent in the state of Parana to 61.8 percent in Bahia. In the United States 2000, the highest percentages of black women were found in the District of Columbia (37.3 percent) and Mississippi (24.9 percent), and the lowest percentages were in Vermont and Montana (less than 1 percent). In Cuba, the percentage of black women ranged from 2.6 percent in the province of Granma to 13.4 percent in Santiago de Cuba.

Next, we present the results of the analysis. First, we provide some descriptive statistics for patterns of racial intermarriage across countries. Second, we use log-linear models to decompose such patterns into main effects and interactions between racial groups after controls. Log-linear models are widely used in inter- 
marriage research (e.g., Qian 1997; Fu, 2001; Schwartz and Mare 2012; Gullickson and Torche 2014).

\section{Descriptive Findings}

Table 1 provides information on the distribution of women in unions aged 25 to 34 by race, educational attainment, and country. Results for men are not reported here because they are very similar to those of women. The last column of Table 1 shows the racial composition of women aged 25 to 34 in unions in Brazil 2000, Cuba 2002, and the United States 2000. White women in Brazil 2000 account for 55.9 percent of the population, whereas mulato and black women account for 37.4 percent and 5.4 percent, respectively. In Cuba, white women represent 67.6 percent, mulato women represent 25.1 percent, and black women represent 7.4 percent of the population under analysis. In the United States, 69.2 percent of women were enumerated as white, and 7.6 percent were enumerated as black. In all countries, white women account for more than 50 percent of the population, and black women account for less than 10 percent. Mulato women account for one-third of the population in Brazil and for one-fourth of the population in Cuba. In the United States, the "other" category represents one-fourth of the population. This mainly consists of Hispanic and Asian American populations.

There are substantial racial gaps in educational attainment in all countries (Table 1). In Brazil, the percentage of white women with higher education (12.3 percent) is 4.5 times larger than among black (2.7 percent) and four times larger than among mulato women (3.1 percent). In the United States, 43.2 percent of white women have completed college education compared with only 27.8 percent of black women. The racial gap in educational attainment in Cuba is substantially lower than in Brazil and in the United States. The share of Cuban women with higher education is similar across racial categories: 13.2 percent among white, 11.1 percent among black, and 8.9 percent among mulato women.

Table 2 displays the percentage of racially endogamous unions by women's race and educational attainment. Racially endogamous couples account for 68.3 percent of all couples in Brazil 2000, 74.9 percent in Cuba, and 90.4 percent in the United States. White women are the most endogamous: 73.3 percent, 84.7 percent, and 93.8 percent of white women in Brazil, Cuba, and the United States, respectively, were married to (or cohabiting with) white men. Black and white women have similar levels of endogamy in the United States. However, black and mulato women in Cuba and Brazil have lower levels of endogamy than whites.

Racial endogamy varies by level of educational attainment, in particular in Brazil and Cuba. In these countries, there is a positive relationship between education and endogamy for white women and a negative relationship for mulato women. Among black women, this relationship is slightly negative in Brazil and positive in Cuba.

Finally, Table 3 shows the relative distribution of unions cross-classified by the race of spouses. White-white couples represent 41.0 percent of all couples in Brazil, 57.2 percent in Cuba, and 64.9 percent in the United States. Under random distribution, the expected share of white-white unions would have been 29.9 percent in Brazil, 45.2 percent in Cuba, and 45 percent in the United States. The 
Table 1: Educational attainment by race; women in unions aged 25 to 34 (Brazil 2000, Cuba 2002, and the United States 2000).

\begin{tabular}{|c|c|c|c|c|c|c|c|}
\hline Country & $\begin{array}{c}\text { Low } \\
0-3\end{array}$ & $\begin{array}{c}\text { Medium low } \\
4-7\end{array}$ & $\begin{array}{l}\text { Medium high } \\
\quad 8-11\end{array}$ & $\begin{array}{c}\text { High } \\
12+\end{array}$ & Total & $\mathrm{N}$ & $\%$ \\
\hline \multicolumn{8}{|l|}{ Brazil 2000} \\
\hline White & $13.3 \%$ & $33.5 \%$ & $40.9 \%$ & $12.3 \%$ & $100 \%$ & 315,340 & $55.9 \%$ \\
\hline Mulato & $27.1 \%$ & $38.1 \%$ & $31.7 \%$ & $3.1 \%$ & $100 \%$ & 210,944 & $37.4 \%$ \\
\hline Black & $29.7 \%$ & $37.9 \%$ & $29.6 \%$ & $2.7 \%$ & $100 \%$ & 30,626 & $5.4 \%$ \\
\hline Other & $28.7 \%$ & $27.7 \%$ & $31.2 \%$ & $12.4 \%$ & $100 \%$ & 7,376 & $1.3 \%$ \\
\hline \multirow[t]{2}{*}{ Total } & $19.6 \%$ & $35.4 \%$ & $36.7 \%$ & $8.3 \%$ & $100 \%$ & 564,286 & $100 \%$ \\
\hline & Primary & $\begin{array}{c}\text { Lower } \\
\text { secondary }\end{array}$ & $\begin{array}{l}\text { Secondary } \\
\text { completed }\end{array}$ & $\begin{array}{l}\text { College } \\
\text { completed }\end{array}$ & & & \\
\hline \multicolumn{8}{|l|}{ Cuba 2002} \\
\hline White & $12.2 \%$ & $31.4 \%$ & $43.3 \%$ & $13.2 \%$ & $100 \%$ & 41,050 & $67.6 \%$ \\
\hline Mulato & $14.5 \%$ & $35.4 \%$ & $41.2 \%$ & $8.9 \%$ & $100 \%$ & 15,220 & $25.1 \%$ \\
\hline Black & $9.0 \%$ & $33.4 \%$ & $46.5 \%$ & $11.1 \%$ & $100 \%$ & 4,488 & $7.4 \%$ \\
\hline \multirow[t]{2}{*}{ Total } & $12.5 \%$ & $32.5 \%$ & $43.0 \%$ & $12.0 \%$ & $100 \%$ & 60,758 & $100 \%$ \\
\hline & $\begin{array}{l}\text { No high school } \\
\text { diploma }\end{array}$ & $\begin{array}{l}\text { High school } \\
\text { diploma }\end{array}$ & $\begin{array}{l}\text { Some } \\
\text { college }\end{array}$ & $\begin{array}{c}\text { College } \\
\text { completed }\end{array}$ & & & \\
\hline \multicolumn{8}{|l|}{ United States 2000} \\
\hline Non-hispanic white & $7.1 \%$ & $24.7 \%$ & $24.9 \%$ & $43.2 \%$ & $100 \%$ & 425,121 & $69.2 \%$ \\
\hline Non-hispanic black & $12.4 \%$ & $28.4 \%$ & $31.1 \%$ & $28.2 \%$ & $100 \%$ & 46,624 & $7.6 \%$ \\
\hline Other & $31.6 \%$ & $22.0 \%$ & $18.5 \%$ & $27.8 \%$ & $100 \%$ & 142,857 & $23.2 \%$ \\
\hline Total & $13.2 \%$ & $24.4 \%$ & $23.9 \%$ & $38.5 \%$ & $100 \%$ & 614,602 & $100 \%$ \\
\hline
\end{tabular}

Source: Own calculations based on census microdata, IPUMS.

observed figures are 36 percent higher in Brazil, 26 percent higher in Cuba, and 45 percent higher in the United States than expected. Intermarried couples account for 31.8 percent of couples in Brazil, 25.1 percent in Cuba, and only 1.2 percent in the United States if we exclude the "other" category. The most frequent type of intermarriage is between white and mulato, which basically reflects the size of these groups in the total population. Regarding gender differences, the percent of couples involving white women and black men in the United States is three times larger than the percentage of couples involving black women and white men ( 0.9 percent versus 0.3 percent). Because the absolute size of the group affects the distribution of couples, in the next section, we turn to log-linear models to measure the interaction between racial groups, controlling for the constraints of the racial composition of the population in unions and other factors.

\section{Log-Linear Models}

In Table 4, we show endogamy levels (expressed in odds ratios) for three types of couple combinations in Brazil and Cuba (white/mulato, white/black, and mulato/black) and one in the United States (white/black). These levels are derived from a series of log-linear models. Table 4 provides goodness-of-fit statistics ( $X^{2}$ and Bayesian information criterion [BIC]) for each model. For every country and 
Table 2: Percentage of endogamous unions by race and educational attainment; women in unions aged 25 to 34 (Brazil 2000, Cuba 2002, and the United States 2000).

\begin{tabular}{lccccc}
\hline & Low & Medium Low & Medium High & High & Total \\
\hline Brazil 2000 & & & & & \\
$\quad$ White & $60.0 \%$ & $70.0 \%$ & $75.9 \%$ & $88.1 \%$ & $73.3 \%$ \\
Mulato & $71.8 \%$ & $65.7 \%$ & $60.2 \%$ & $50.7 \%$ & $65.2 \%$ \\
Black & $47.6 \%$ & $45.4 \%$ & $43.8 \%$ & $44.0 \%$ & $45.5 \%$ \\
Other & $54.0 \%$ & $32.3 \%$ & $32.5 \%$ & $46.3 \%$ & $40.3 \%$ \\
$\quad$ Total & $65.0 \%$ & $66.5 \%$ & $69.0 \%$ & $81.2 \%$ & $68.3 \%$ \\
Cuba 2002 & & & & & \\
$\quad$ White & $81.4 \%$ & $82.7 \%$ & $85.8 \%$ & $89.2 \%$ & $84.7 \%$ \\
Mulato & $58.4 \%$ & $54.2 \%$ & $54.4 \%$ & $53.4 \%$ & $54.8 \%$ \\
Black & $43.8 \%$ & $49.0 \%$ & $56.1 \%$ & $58.7 \%$ & $52.9 \%$ \\
Total & $72.7 \%$ & $72.4 \%$ & $75.9 \%$ & $80.5 \%$ & $74.9 \%$ \\
United States 2000 & & & & & \\
$\quad$ Non-hispanic white & $91.6 \%$ & $93.8 \%$ & $92.9 \%$ & $94.6 \%$ & $93.8 \%$ \\
Non-hispanic black & $95.2 \%$ & $95.1 \%$ & $93.5 \%$ & $92.3 \%$ & $93.8 \%$ \\
Other & $94.2 \%$ & $80.0 \%$ & $68.9 \%$ & $69.0 \%$ & $79.4 \%$ \\
Total & $93.3 \%$ & $91.0 \%$ & $88.6 \%$ & $90.2 \%$ & $90.4 \%$ \\
\hline
\end{tabular}

Source: Own calculations based on census microdata, IPUMS.

year, the same set of models apply. In the interests of comparability across countries, these models avoid complex interactions and topological structures (see full description in Appendix 3 of the online supplement). The input data consisted of contingency tables where couples in which women aged 25 to 34 were crossclassified according to various dimensions: race of the spouses (model 1 [M1]); race of the spouses and geography (model 2 [M2]); race of the spouses, geography, and type of union (model 3 [M3]); and race of the spouses, geography, type of union, and educational attainment of the spouses (model 4 [M4] and model 5 [M5]). ${ }^{7}$ The focus is on the interaction between the races of the spouses and comparing these interactions across countries. We included additional dimensions in models 2 to 5 as control variables.

Model 1 (Table 4) shows that whites, mulatos, and blacks tend to marry within their own racial group. The odds ratios (O.R.s) are well above 1 in all countries and across all racial pairings. The highest levels of endogamy, and thus, lowest levels of intermarriage, are found between whites and blacks, although countries differ substantially in their levels. By a large margin, white-black endogamy is greater in the United States (O.R. $=2,160.1)$ than in Cuba (O.R. = 81.6) and Brazil (O.R. = 31.6). Whites in Brazil are 31 times more likely to marry whites than blacks are to marry whites. The level of endogamy among whites and blacks in Brazil is extremely low if compared with the figure of the United States, where whites are more than 2,000 times more likely to marry whites than blacks. In Brazil and Cuba, where mulato populations are included in the analysis, the level of endogamy among whites and blacks is higher than that observed between whites and mulatos and between mulato and black populations. Nevertheless, the pattern of intermarriage of the mulato population in Brazil is different from that of the population in Cuba. In 
Table 3: Distribution of unions by race of the partners; women in unions aged 25 to 34 (Brazil 2000, Cuba 2002, and the United States).

\begin{tabular}{lrrrrr}
\hline Women's race & \multicolumn{5}{c}{ Men's race } \\
Brazil 2000 & White & Mulato & Black & Other & Total \\
$\quad$ White & 41.0 & 12.4 & 2.0 & 0.5 & 55.9 \\
Mulato & 10.7 & 24.4 & 2.1 & 0.3 & 37.4 \\
Black & 1.6 & 1.3 & 2.5 & 0.1 & 5.4 \\
Other & 0.4 & 0.3 & 0.1 & 0.5 & 1.3 \\
$\quad$ Total & 53.6 & 38.4 & 6.7 & 1.3 & $100 \%$ \\
Cuba 2002 & & & & & \\
$\quad$ White & 57.2 & 8.5 & 1.8 & - & 67.5 \\
Mulato & 8.2 & 13.8 & 3.1 & - & 25.1 \\
Black & 1.5 & 2.0 & 3.9 & - & 7.4 \\
Other & - & - & - & - & - \\
$\quad$ Total & 67.0 & 24.2 & 8.8 & - & $100 \%$ \\
United States 2000 & & & & & \\
$\quad$ White & 64.9 & - & 0.9 & 3.5 & 69.2 \\
$\quad$ Mulato & - & - & - & - & - \\
Black & 0.3 & - & 7.1 & 0.2 & 7.6 \\
Other & 4.2 & - & 0.5 & 18.5 & 23.2 \\
$\quad$ Total & 65.1 & - & 8.5 & 22.1 & $100 \%$ \\
\hline
\end{tabular}

Source: Own calculations based on census microdata, IPUMS.

Brazil, endogamy among whites and mulato populations is lower (O.R. $=7.5)$ than in mulato and black populations $(\mathrm{O} . \mathrm{R} .=21.5)$. This means that mulato populations in Brazil are far more likely to marry whites than blacks. In Cuba, endogamy levels in whites and mulato populations, and mulato and black populations, have similar values (O.R.s $=11.2$ and 8.9, respectively).

The racial stratification pattern that emerges from model 1 is repeated in model 2 through model 5. Even when controls are applied, the United States emerges as the most endogamic country. Model 2 measures racial endogamy by controlling for the racial composition of each state (Brazil or the United States) or province (Cuba). Model 2 yields slightly lower levels of racial endogamy than model 1 . For instance, white-black endogamy levels declined between M1 and M2, from 31.6 to 24.2 in Brazil, from 81.6 to 67.6 in Cuba, and from 2,160 to 1,904 in the United States.

Model 3 controls for type of union and adds an interaction between type of union and racial endogamy. This model yields endogamy parameters for cohabiting and married unions. Married unions are more endogamous than unmarried ones. On average, the white-black endogamy level among married couples is 2.8 times greater than among cohabiting couples in Brazil, 4.2 times greater in Cuba, and 4.3 times greater in the United States.

Model 4 controls for the educational attainment of the spouses and for educational assortative mating. Even though model 4 proves that education is a strong structuring dimension of the marriage market (results not shown), the overall level of racial endogamy has not changed substantially compared with previous models. 
Table 4: Distribution of unions by race of the partners; women in unions aged 25 to 34 (Brazil 2000, Cuba 2002, and the United States).

\begin{tabular}{|c|c|c|c|c|c|}
\hline \multirow[b]{2}{*}{ Model } & \multirow[b]{2}{*}{$\mathrm{X} 2$} & \multirow[b]{2}{*}{$\mathrm{BIC}$} & \multicolumn{3}{|c|}{ Odds ratios for endogamous unions } \\
\hline & & & $\begin{array}{l}\text { White/ } \\
\text { Mulato }\end{array}$ & $\begin{array}{c}\text { White/ } \\
\text { Black }\end{array}$ & $\begin{array}{c}\text { Mulato/ } \\
\text { Black }\end{array}$ \\
\hline \multicolumn{6}{|l|}{ Brazil 2000} \\
\hline M1. Racial endogamy & 3,971,318.7 & $1,279,011.7$ & 7.5 & 31.6 & 21.5 \\
\hline M2. M1. + Geography & $923,559.9$ & $561,656.3$ & 5.0 & 24.2 & 18.9 \\
\hline M3. M2. + Racial endogamy by type of union & $738,175.9$ & $482,624.9$ & & & \\
\hline Cohabitation & & & 3.9 & 12.7 & 13.7 \\
\hline Marriage & & & 5.6 & 35.8 & 25.5 \\
\hline M4. M3. + Educational assortative mating & $21,752.7$ & $-128,589.7$ & 4.3 & 19.5 & 18.6 \\
\hline M5. M4. + Racial endogamy by education & $21,166.4$ & $-128,654.9$ & & See Figure & \\
\hline \multicolumn{6}{|l|}{ Cuba 2002} \\
\hline M1. Racial endogamy & $163,183.2$ & $52,083.3$ & 11.2 & 81.6 & 8.9 \\
\hline M2. M1. + Geography & $84,796.6$ & $23,127.3$ & 6.8 & 67.6 & 6.7 \\
\hline M3. M2. + Racial endogamy by type of union & $73,483.5$ & $18,304.5$ & & & \\
\hline Cohabitation & & & 5.0 & 36.0 & 5.7 \\
\hline Marriage & & & 9.9 & 151.4 & 8.2 \\
\hline M4. M3. + Educational assortative mating & $4,733.0$ & $-31,287.5$ & 6.5 & 72.7 & 6.9 \\
\hline M5. M4. + Racial endogamy by education & $4,558.8$ & $-31,273.0$ & & See Figure & \\
\hline \multicolumn{6}{|l|}{ United States 2000} \\
\hline M1. Racial endogamy & $6,039,363.6$ & $1,454,922.3$ & & 2,160 & \\
\hline M2. M1. + Geography & $1,578,744.0$ & $761,265.7$ & & 1,904 & \\
\hline M3. M2. + Racial endogamy by type of union & $757,270.2$ & $360,328.3$ & & & \\
\hline Cohabitation & & & & 593. & \\
\hline Marriage & & & & 2,555 & \\
\hline M4. M3. + Educational assortative mating & $31,883.5$ & $-121,276.3$ & & 2,046 & \\
\hline M5. M4. + Racial endogamy by education & $28,933.6$ & $-124,997.5$ & & See Figure & \\
\hline
\end{tabular}

Note: All coeficients are statitstically signficant at the 0.05 level. See Appendix 3 of the online supplement for the full description of the models. Source: Own calculations based on census microdata, IPUMS.

This result suggests that education and race are, to a certain extent, independent dimensions of the marriage market.

Figure 1 represents graphically the odd ratios for endogamous unions by race and country yielded by model 4 . We use a logarithmic scale on the vertical axis to accommodate the large differences that exist between the United States on the one hand and Brazil and Cuba on the other. The United States presents the highest level of white-black endogamy. In the United States, whites and blacks are more than 2,000 times more likely to marry within their group than blacks and whites are to intermarry. White and black endogamy levels in Brazil and Cuba are substantially lower than in the United States. We can easily quantify the differences between countries by comparing odds ratios across them. White-black intermarriage was 105 times more likely to occur in Brazil than in the United States $(2046.5 / 19.5=105)$ and almost 30 times more common in Cuba than in the United States (2046.5/72.7 $=28.2$ ). White-black intermarriage in Brazil is 3.7 times more likely than in Cuba $(72.7 / 19.5=3.7)$.

Intermarriage between white and mulato populations in Brazil is lower than intermarriage between mulato and black populations. This implies that mulato populations marry whites more than blacks: Intermarriage between mulatos and whites is 4.3 times more likely to occur than between mulatos and blacks (18.6/4.3 
$=4.3)$. By contrast, mulato populations in Cuba intermarry roughly equally with blacks (O.R. $=6.9)$ and whites (O.R. $=6.5)$.

Model 5 includes an interaction between racial endogamy and educational attainment. Results are shown in Figures 2 and 3 (and in Appendix 1 of the online supplement). Figure 2 shows the odds ratio of white-black endogamy by level of education in Brazil, Cuba, and the United States. A value of 1 indicates that at that particular level of education, intermarriage is random between whites and blacks. Thus, there is no tendency towards endogamy. Given the large differences in endogamy levels between the United States on one side and Brazil and Cuba on the other, we use a logarithmic scale to represent odds ratios. In Brazil and Cuba, there is a positive relationship between education and endogamy. This means that intermarriage between whites and blacks lessens with educational attainment. High-educated women in Cuba (O.R. $=187.2)$ are 4.3 times more endogamous than low-educated women (O.R. $=42.9)$. Men show similar patterns than women. In Brazil, endogamy levels among high-educated men and women are 2.4 and 2.9 times larger than among low-educated men and women, respectively. Unlike Brazil and Cuba, the United States shows a modest and negative relationship between education and endogamy.

These results point to a significant distinction between Brazil and Cuba on the one hand and the United States on the other. Intermarriage between whites and blacks is more likely to occur among men and women with the lowest education in Brazil and Cuba but most likely to occur among men with the highest levels of education in the United States. U.S. women show no clear pattern by education.

Finally, Figure 3 shows the white-mulato and the mulato-black racial endogamy levels by educational attainment and sex in Brazil and Cuba. This figure is organized into four panels, each one representing one country and type of racial pairing (white-mulato and mulato-black). Compared to white-black intermarriage, mulato populations show lower levels of endogamy either with respect to blacks or whites. In all combinations, there is a slight but positive relationship between endogamy and educational attainment.

\section{Summary}

The United States has been the focus of the vast majority of studies of black-white intermarriage. In this article, we have sought to decenter the study of interracial marriage away from the United States by directly comparing it with the cases of Brazil and Cuba, where histories of slavery involving Africans have been even more prominent than in the United States. In both Latin American countries, narratives of mestizaje or race mixture since slavery have dominated thinking about race, suggesting greater intermarriage (or less racial endogamy) than in the United States, but once the relevant variables were adjusted, it was not clear how much. We also expected Cuba to have more intermarriage than Brazil because of the former's racial educational equality, where education had been significantly upgraded among all social sectors.

Using the same analytical strategy to examine the three countries with newly released IPUMS-I census microdata from the 2000 round of censuses, we find that 

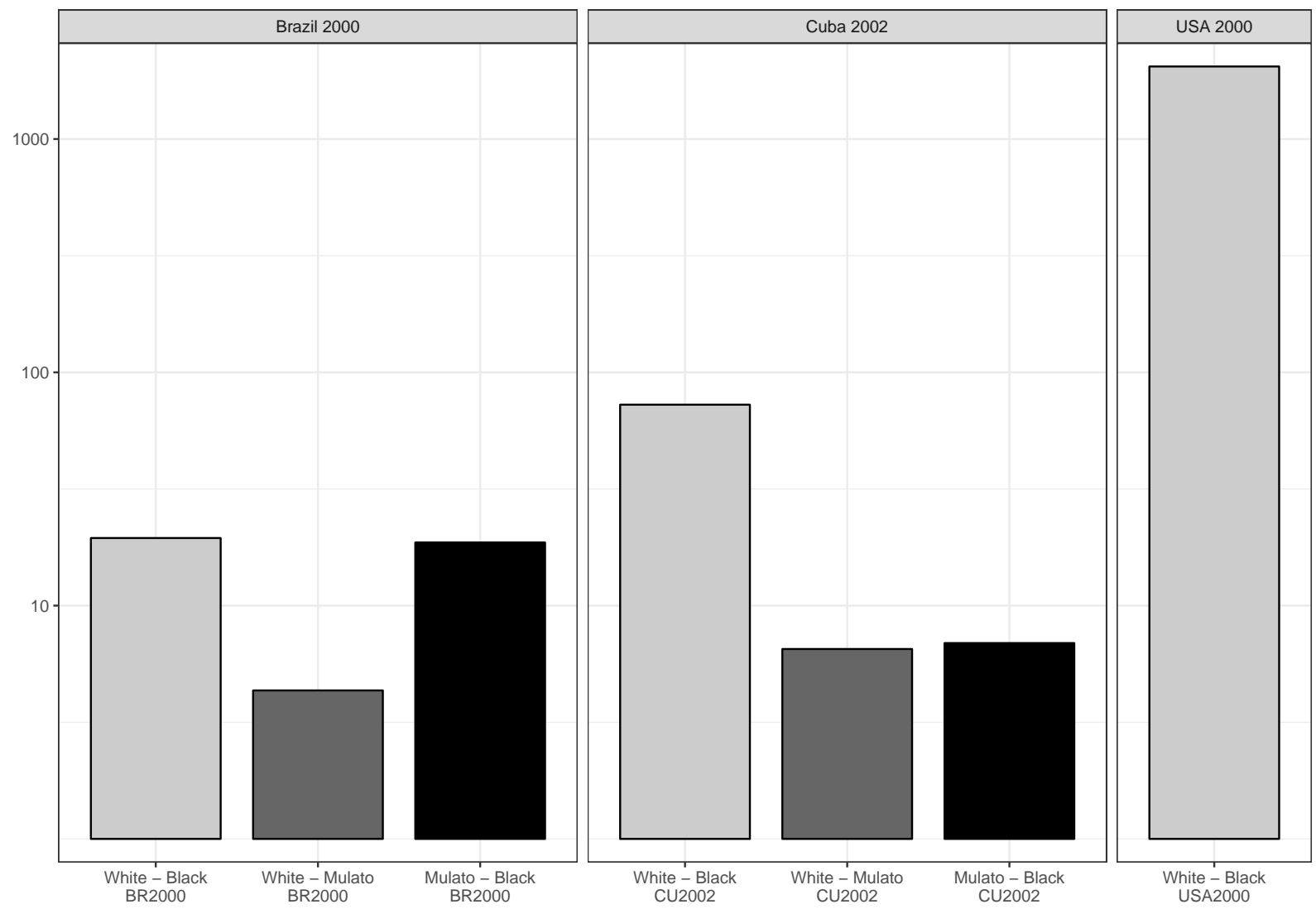

Figure 1: Estimated odds ratios for racially endogamous pairings among married and cohabiting unions of women aged 25 to 34 in Brazil 2000, Cuba 2002, and the United States 2000 (Model 4). Source: Own calculations based on census microdata, IPUMS.

black-white intermarriage in the 2000s is fully 105 times as likely to occur in Brazil and 28 times as likely to occur in Cuba compared with in the United States. Our findings confirm that racial boundaries between whites and blacks are particularly rigid in the United States compared with in Cuba and Brazil. However, we also found black-white intermarriage to be 3.7 times as great in Brazil compared with in Cuba, contrary to our initial expectations.

We also examined intermarriage of the mulato population to both whites and blacks in Brazil and Cuba. Since the early twentieth century, there has been no comparable category for the United States, and thus modern studies of racial intermarriage have not examined this category. We found that mulatos are more likely to marry blacks and whites than blacks and whites are likely to marry each other, in both countries. Although there has been a tendency to lump blacks and mulatos in Brazil, our data have revealed the merits of disaggregating them. First of all, mulato-white marriages are clearly more frequent than black-white marriages. In Brazil, mulato-white marriages are fully 4.5 times as likely to occur as white-black marriages, and in Cuba, the comparable figure is 11.2 times. Secondly, in a finding 

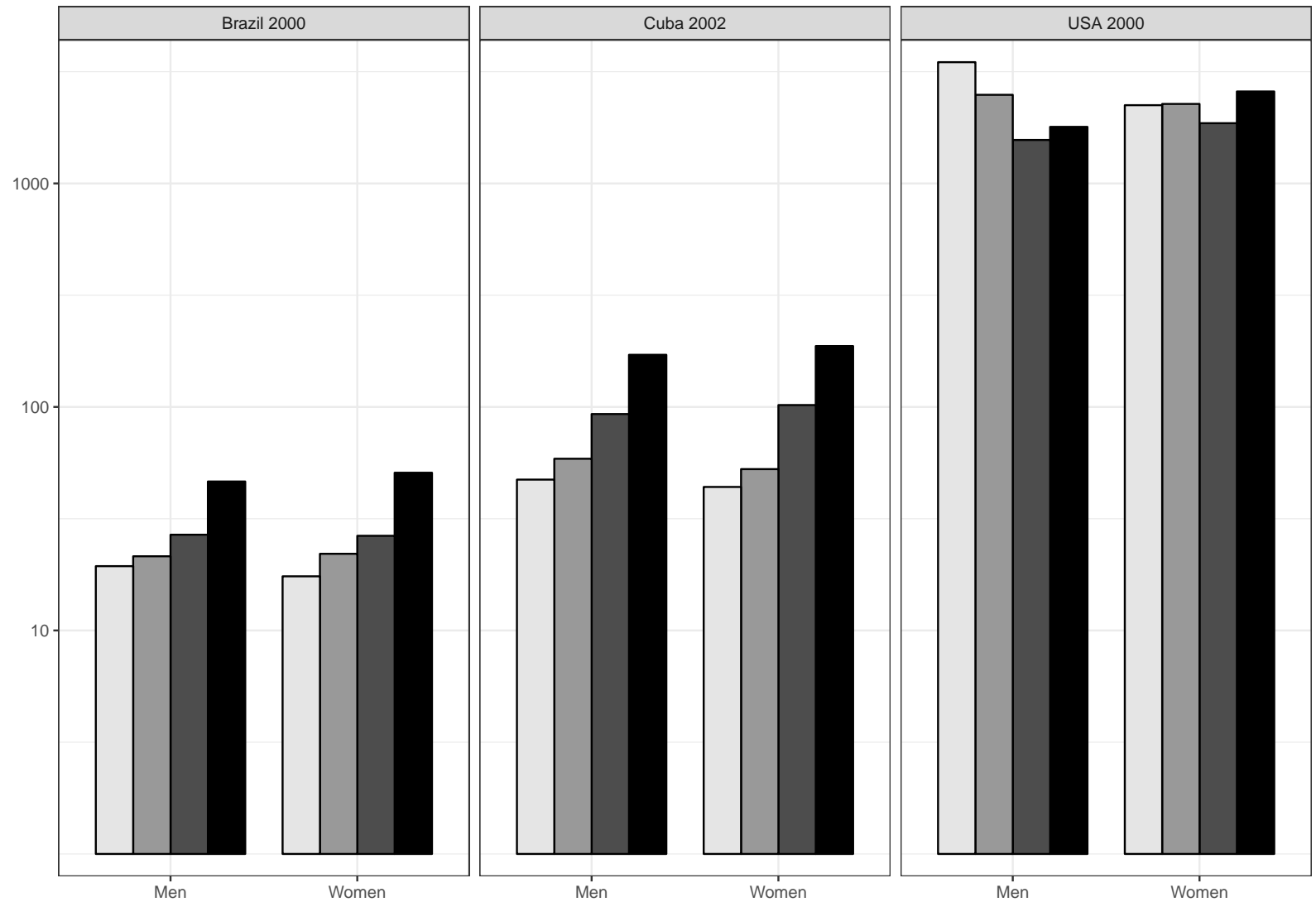

Figure 2: Estimated odds ratios for endogamy levels between whites and blacks by educational attainment among married and cohabiting unions of women aged 25 to 34 in Brazil 2000, Cuba 2002, and the United States 2000 (model 5). Source: Own calculations based on census microdata, IPUMS.

that surprised us, mulatos are closer to whites in Brazil, whereas they are midway between whites and blacks in Cuba. Specifically, Brazilian mulatos are 4.3 times as likely to marry whites as they are to marry blacks, but in Cuba, mulatos are equally likely (1.05 times) to marry blacks compared with whites. From a cross-national perspective, our findings also reveal that mulato-black intermarriages are actually more common in Cuba. Brown-black marriages are less than half as likely (0.4) to occur in Brazil compared with Cuba, whereas white-brown marriages are 50 percent more likely (1.5) in Brazil; this compares to black-white marriages, which are four times more frequent in Brazil than in Cuba.

Racial intermarriage patterns persist at all educational levels, in all types of unions, and in every state/province of residence. Controls for the unequal distribution of racial groups across regions, for differences between married and cohabiting unions, and for the educational distribution of racial groups hardly affected rates of intermarriage in any country. Married couples are more racially endogamous than cohabiting couples, and educational differences across racial groups hardly reduce the odds ratio of racial endogamy compared with models that do not take 

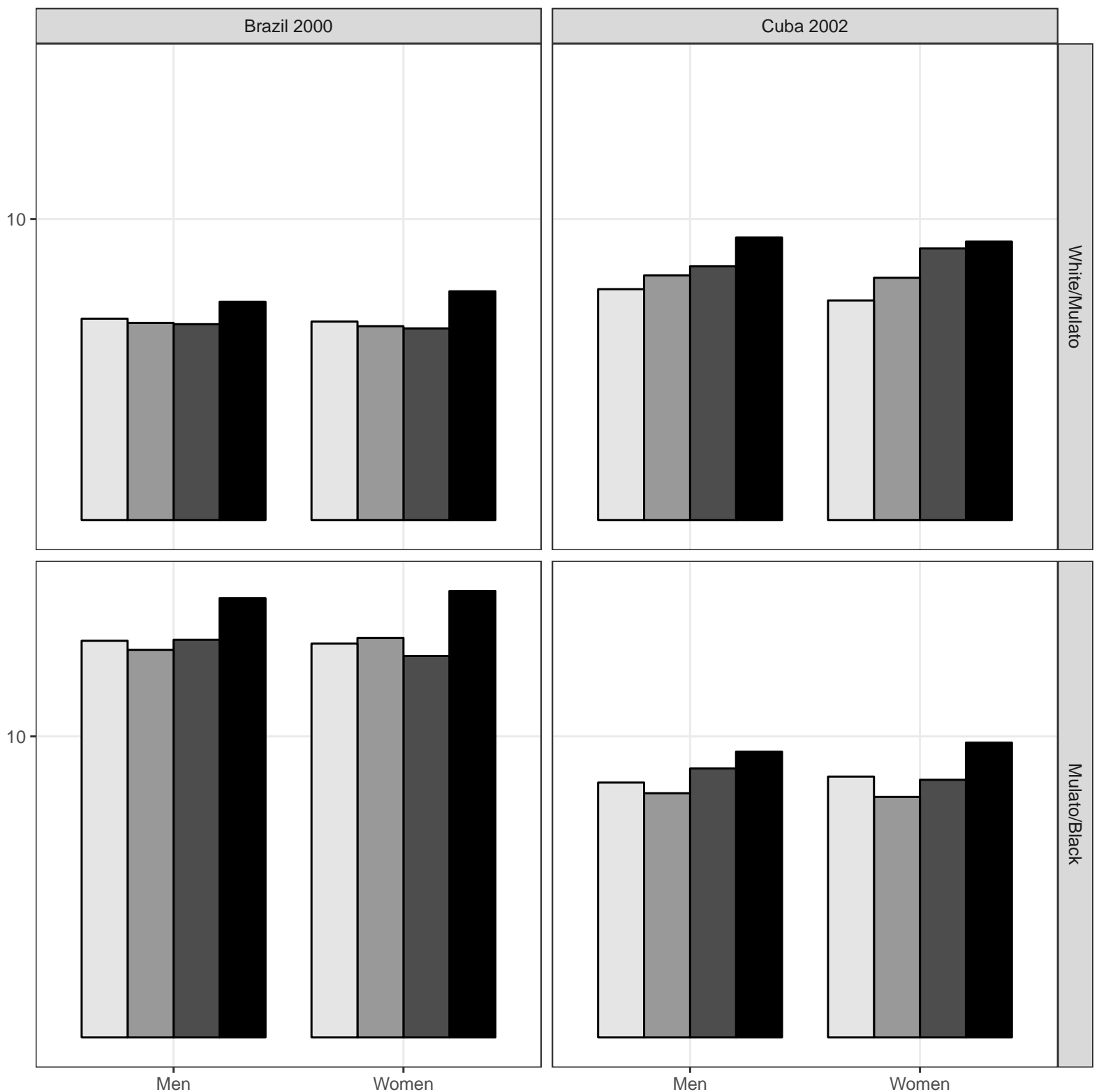

Figure 3: Estimated odds ratios for endogamy levels between mulato-black and white-mulato racial pairings by educational attainment among married and cohabiting unions of women aged 25 to 34 in Brazil 2000, Cuba 2002, and the United States 2000 (model 5). Source: Own calculations based on census microdata, IPUMS.

into account the educational attainment of the spouses. Surprisingly, even in a country like Cuba, where controls for educational attainment would have been less necessary than in Brazil and the United States because there are hardly any racial gaps in educational attainment among young generations, there is a strong tendency to marry within racial groups. This shows the strength of racial preferences despite educational equality. 
Finally, patterns along the educational gradient are striking. In the United States, we found no educational gradient in the white-black endogamy levels among women but a negative gradient for men. This is not surprising, as it supports previous literature (e.g., Qian and Lichter 2007). However, these gradients are slight compared with those we found for Brazil and Cuba. In both Latin American countries, the educational gradient is positive and relatively steep from all gender perspectives. Black-white endogamy levels increase by educational attainment. In other words, unlike the United States, intermarriage notably increases among persons with progressively lower education. Thus, ongoing mestizaje in these two Latin American nations, where it occurs, is primarily among persons of low socioeconomic status. In sum, racial boundaries are relatively rigid in the United States and least rigid in Brazil, with Cuba being intermediate, but racial intermarriage is concentrated among the low-status sectors of Brazil and Cuba, whereas there is no clear status pattern for the United States.

\section{Discussion and Conclusion}

We find that black-white intermarriage is 105 times as likely in Brazil and 28 times as likely in Cuba compared with in the United States. All three countries have histories of European colonization and settlement, with extensive histories of slavery of Africans, and all are characterized by persistent racial discrimination where whiteness is privileged and blackness is stigmatized. At a general Latin American level, keeping in mind that the Latin American evidence is overwhelming from Brazil with supporting evidence from other countries, differences with the United States are large. Although we do not have historical data, we venture to explain these differences with a theory of intergenerational mixture and intermarriage, in which a male-dominated sex ratio spawned mixed-race populations that grew in subsequent generations. These pairings and a growing mulato population created a culture of mixture and intermarriage, which was further promoted through stateendorsed narratives of mestizaje after independence. Through interracial marriage or concubinage, families and social networks of the partners are comingled, making such pairings increasingly normative. Over several generations and with state and elite endorsement of racial mixture narratives (mestizaje) that resonate well with local culture and become cultural-social (or racial) scripts (Swidler 1986), intermarriage becomes normative on a widespread basis at least among particular class sectors of the population. In other words, race mixture, originally sustained by a high sex ratio and later perpetuated by national ideologies, would lead to intergenerationally transmitted cultural scripts and practices that accepted race mixture to some extent. Such processes have been almost completely absent in the United States.

Indeed, the opposite has occurred in the United States, through racial separation laws and policies, including racial segregation and antimiscegenation, as well as ideas of racial purity. Certainly, the end of such policies and changing attitudes have led to an increase in intermarriage (Fryer 2007; Qian and Lichter 2007) but at levels that continue to pale in comparison to Cuba and especially Brazil. Since the end of antimiscegenation and segregation laws in the United States, intermarriage 
continues to be uncommon, presumably reflecting the persistence of an especially strong cultural taboo in which whites reject blacks as marriage partners. Structurally, actual segregation has declined slowly and friendship networks have been slow to integrate, maintaining limited black-white contact. In sum, at the level of preferences, the rejection of blacks as marriage partners was probably not nearly as great in the Latin American countries as in the United States, and in terms of opportunities, levels of interracial contact or exposure have also been greater in Brazil (Telles 2004) and presumably in Cuba than in the United States.

But the general theory about Latin America does not explain significant CubaBrazil differences. We expected black-white intermarriage to be greater in Cuba, mostly because structural differences between races are far smaller than in Brazil. However, we were surprised to find that black-white intermarriage rates are more than four times greater in Brazil compared with in Cuba, and these differences held up regardless of educational levels, where inequality is at world-class levels in Brazil and nearly absent in Cuba. Because the social structure of contemporary Cuban society would favor much more intermarriage in Cuba because of its strikingly low levels of inequality, Brazil's higher rates of intermarriage are likely to be found in a stronger culture of intermarriage, thus precluding a single Latin American model.

Although Cuba may have had extensive mixture during colonization, the economic, political, cultural, and social dominance of the United States in pre-Castro Cuba probably shaped more explicit antiblack prejudice and antimixture attitudes in recent generations (de la Fuente 2001; Sawyer 2005). In particular, American influences encouraged segregation; many public and private spaces often excluded blacks and were openly discriminatory, particularly in the middle-class spaces where tourists congregated (de la Fuente 2001:158). Since the early 1960s, Cuba's socialist state dismantled racially exclusive spaces but through class-based language, and it mostly ignored persistent racism even after it was clear that material equality would not eliminate it (de la Fuente 2001; Sawyer 2005; Fernandez 2010). Methodologically, studies of race and ethnicity in Cuba, Brazil, or any other Latin American country, to the extent they make comparisons, tend to compare them with the United States rather than with other Latin American nations, revealing the pitfalls of lumping many countries into a single Latin American model and the persistent primacy of the United States in the field of race and ethnicity.

Negative educational gradients in intermarriage for Brazil and Cuba run contrary to theory that higher education leads to greater universalism and thus greater racial tolerance and intermarriage among the most educated (Kalmijn 1998). In the Brazilian and Cuban cases, universalism, to the extent it may exist, is apparently overwhelmed by an intergenerational culture of mixture and intermarriage that is strongest in the lowest social strata, where interracial pairings become more familiar and thus more accepted or tolerated. In Brazil, centuries-old race mixture has tended to occur at the bottom rungs of society, whereas the elite is exceptional for maintaining its whiteness and distance from blacks and mulatos. Because blacks and mulatos continue to predominate at the bottom of society, although with many whites, the top is overwhelmingly white, and opportunities for intermarriage have clearly been at the bottom. Relatively moderate segregation has also permitted interaction of whites, mulatos, and blacks at levels that are uncommon in the United 
States. In Cuba, there are small differences in the proportions by educational level in recent decades, but we expect that prerevolutionary (pre-1959) class differences in norms about mixture and intermarriage could lead to positive educational gradients decades later.

We found large differences in the position of mulatos in Cuba and Brazil, where Cuban mulatos occupy a midway status between whites and blacks in Cuba, whereas they are clearly closer to whites in Brazil. Thus, the Cuban case is clearly consistent with mulato escape hatch theory (Degler 1971), whereas the Brazilian findings are surprising. Unfortunately, we know almost nothing about the mulato case in Cuba, as previous work has tended to aggregate blacks and mulatos.

For the United States, the population considered mulato, biracial (black/white), or similar in the U.S. census (by virtue of identifying as both black and white) is much smaller than in Brazil and Cuba and too small to produce a reliable estimate, although the numbers are growing. The fact that Americans of mixed black-white ancestry were defined as black, and thus unable to escape from the black category, itself supports the historical absence of a mulato escape hatch in the United States. Moreover, it reveals that the astoundingly low level of American black-white intermarriage may be an overestimate insofar as it includes people who would be considered mulato in Latin America, who are socially closer to whites than blacks. Using Latin American black-mulato distinctions, the actual black-white intermarriage level in the United States thus might actually be even lower than the figures we computed.

Whereas Cuban mulatos are about equally likely to marry whites or blacks, Brazilian mulatos are fully four times as likely to marry whites compared with blacks. This outcome stands in direct contrast to the well-known findings that mulatos and blacks share similar educational and income levels (do Valle Silva 1985), which led to the demise of mulato escape hatch thinking. On the other hand, later findings have shown that Brazilian mulatos are actually midway between whites and blacks after controls for education and so on (Telles and Lim 1998; Bailey, Loveman, and Muniz 2013). Our findings for intermarriage might result from a combination of social whitening and greater tolerance in the Brazil case. Under this possible explanation, Brazilian mulatos are more likely to seek out white partners, as whitening continues to be valued, whereas Brazilian whites are more accepting of mulatos as marriage partners than Cuban whites, as higher overall rates of intermarriage suggest.

Relatedly, our findings challenge the common aggregation of the black and mulato categories into a single black category because they were found to share a similar vertical position. Certainly, there may be many good reasons to aggregate, which has become common practice, but that should not impede continued research into black-mulato differences, which may vary not only internationally but across different dimensions in the same country.

\section{Notes}

1 Although the proportion of whites married to blacks steadily increased by several times from 1960 to 2000, only about 0.90 percent of married white men and 0.45 percent 
of married white women were married to blacks in 2000 (Fryer 2007). This figure is particularly striking considering that blacks constitute about 12 percent of the national population.

2 The census terms are mulato o moreno in Cuba and pardo in Brazil. Mulato refers to the mixture of black and white persons, moreno generally refers to brown persons, and pardo translates as brown and is often used to describe Brazil's population of partly African ancestry (Stephens 1989). Given the large population of enslaved Africans in both countries, these mixed-race categories are assumed to consist predominately of persons with African ancestry.

3 Also, analysts have noted that the "special period" since the end of Soviet subsidies in 1992 heightened racial inequality, giving whites far greater access to the hard currency introduced by immigrant remittances and the growing tourist industry (de la Fuente 2001; Sawyer 2005; Fernandez 2010). Cuban spokespersons continue to promote claims that they have also overcome racism and racial discrimination (Cave 2016; Aznarez 2016).

4 A mulato category has been used in Brazil (pardo) and Cuba (mulato) in most censuses since the nineteenth century (Loveman 2014), and the persistence of mixed-race categories has been used as proof of the importance of race mixture in Latin America. However, the existence of a pardo or mulato category in Brazil and Cuba is both cause and consequence of an ideology of race mixture and not an automatic result of actual race mixture. Note that mulato persons in Brazil are defined by color as well as ancestry. Also, they are the progeny of many generations of racial mixture and not necessarily of the past generation.

5 Ethnographic studies have sometimes favored using a bipolar system of race while referring to mulato/black distinctions as phenotypical or color based because the subjects themselves often have similar understandings of race, phenotype, and color (Osuji 2013; Hordge-Freeman 2015). The reference to race rather than color or phenotype suggests a more essentialistic understanding of such social divisions, although race is based on phenotype or color. Nevertheless, both the bipolar and tripartite systems are popularly used and understood among ordinary Brazilians, probably because both systems are now institutionalized (the tripartite system in the census; official statistics, including affirmative action; and the bipolar system in the media, government, and social movements), and race mixture continues to be a dominant theme (Sheriff 2001; Telles 2004; Cicalo 2012). Importantly, since 1991, the Brazilian census has asked respondents to identify their "color or race," and the Cuban census continues, as it continually has since the nineteenth century, to ask about "color" or "skin color" only (Loveman 2014).

6 We used the spouse location variable available at and constructed by IPUMS (Sobek and Kennedy 2009) to attach spousal characteristics to each partnered person in the household.

7 Person weights are applied to get a representative sample of the total population of couples, but we did not expand the number of couples to the total population.

\section{References}

Adams, Susan M., Elena Bosch, Patricia L. Balaresque, Stéphane J. Ballereau, Andrew C. Lee, Eduardo Arroyo, Ana M. López-Parra, Mercedes Aler, Marina S. Gisbert Grifo, Maria Brion, Angel Carracedo, João Lavinha, Begoña Martínez-Jarreta, Lluis Quintana-Murci, Antònia Picornell, Misericordia Ramon, Karl Skorecki, Doron M. Behar, Francesc Calafell, and Mark A. Jobling. 2008. “The Genetic Legacy of Religious Diversity and Intolerance: 
Paternal Lineages of Christians, Jews, and Muslims in the Iberian Peninsula." The American Journal of Human Genetics 83:725-36. https://doi .org/10.1016/j . ajhg . 2008 .11.007.

Aznarez, Juan Jesús. 2016. “La Revolución se Olvidó del Racismo: El Prejuicio Racial en Cuba No Es Institucional sino Cultural, Ancestral, Arraigado en las Familias." El País March 22. Retrieved March 18, 2019 (https : //elpais .com/internacional/2016/03/22/ actualidad/1458672743_275397.html).

Bailey, Stanley R. 2009. Legacies of Race: Identities, Attitudes, and Politics in Brazil. Stanford, CA: Stanford University Press.

Bailey, Stanley R., Mara Loveman, and Jeronimo O. Muniz. 2013. "Measures of 'Race' and the Analysis of Racial Inequality in Brazil." Social Science Research 42:106-19. https: //doi.org/10.1016/j.ssresearch.2012.06.006.

Barth, Fredrik. 1969. Ethnic Groups and Boundaries: The Social Organization of Cultural Difference. Long Grove, IL: Waveland Press.

Blau, Peter M., and Otis Dudley Duncan. 1967. The American Occupational Structure. New York, NY: John Wiley \& Sons.

Catasús, Sonia. 1989. La Nupcialidad de Los Jóvenes en Cuba: Su Comportamiento General. Havana, Cuba: CEDEM.

Cave, Damien. 2016. “Cuba Says It Has Solved Racism. Obama Isn't so Sure." New York Times March 23. Retrieved March 18, 2019 (https://www.nytimes.com/2016/03/24/world/ americas/obamaurges-raised-voices-incubas-husheddiscussions-ofrace.html).

Cicalo, André. 2012. Urban Encounters: Affirmative Action and Black Identities in Brazil. New York, NY: Palgrave Macmillan US. https : //doi .org/10.1057/9781137096012.

Costa Ribeiro, Carlos A., and Nelson do Valle Silva. 2009. "Cor, Educação e Casamento: Tendência da Seletividade Marital no Brasil, 1960 a 2000." Revista de Ciências Sociais 52:7-51. https://doi.org/10.1590/S0011-52582009000100001.

Davis, Floyd James. 2001. Who Is Black? One Nation's Definition. University Park, PA: The Pennsylvania State University Press.

Davis, Kingsley. 1941. "Intermarriage in Caste Societies." American Anthropologist 43:376-95. https://doi.org/10.1525/aa.1941.43.3.02a00030.

de la Fuente, Alejandro. 2001. A Nation for All: Race, Inequality, and Politics in Twentieth-Century Cuba. Chapel Hill, NC: University of North Carolina Press.

de la Fuente, Alejandro, and George Reid Andrews. 2018. Afro-Latin American Studies: An Introduction. Cambridge, United Kingdom: Cambridge University Press. https: //doi.org/10.1017/9781316822883.

Degler, Carl. 1971. Neither Black nor White: Slavery and Race Relations in Brazil and the United States. Madison, WI: The University of Wisconsin Press.

Dixon, Angela. 2015. "Colorism and Classism Confounded: Perceptions of Discrimination in Latin America." Presented at the Population Association of America Annual Meeting, San Diego, CA. 
do Valle Silva, Nelson. 1985. “Updating the Cost of Not Being White in Brazil." Pp. $42-55$ in Race, Class and Power in Brazil, edited by P. M. Fontaine. Los Angeles, CA: UCLA Center for Afro-American Studies.

do Valle Silva, Nelson. 1987. “Distancia Social e Casamento Inter-racial no Brasil." Estudos Afro-Asiaticos 14:54-84.

Eltis, David. 2017. “African Slave Trade Database." Retrieved August 29, 2017 (http: //www . slavevoyages.org/tast/assessment/estimates.faces).

Eltis, David, Stephen D. Behrendt, David Richardson, and Herbert S. Klein. 1999. The Trans-Atlantic Slave Trade: A Database on CD-ROM. New York, NY: Cambridge University Press.

Esteve, Albert, Ron Lesthaeghe, and Antonio López-Gay. 2012. "The Latin American Cohabitation Boom, 1970-2007." Population and Development Review 38:55-81. https: //doi.org/10.1111/j.1728-4457.2012.00472.x.

Esteve, Albert, and Ron J. Lesthaeghe. 2016. Cohabitation and Marriage in the Americas: Geohistorical Legacies and New Trends. Cham, Switzerland: Springer International Publishing. https://doi.org/10.1007/978-3-319-31442-6.

Fernandes, Florestan. 1965. A Integraçao do Negro na Sociedade de Classes. Sao Paulo, Brazil: Dominus.

Fernandez, Nadine T. 2010. Revolutionizing Romance: Interracial Couples in Contemporary Cuba. New Brunswick, NJ: Rutgers University Press.

Flores, René, and Edward Telles. 2012. "Social Stratification in Mexico." American Sociological Review 77:486-94. https://doi.org/10.1177/0003122412444720.

Fryer, Roland G. 2007. "Guess Who's Been Coming to Dinner? Trends in Interracial Marriage over the 20th Century." Journal of Economic Perspectives 21:71-90. https://doi .org/10. $1257 /$ jep. 21.2 .71 .

Fu, Vincent Kang. 2001. “Racial Intermarriage Pairings.” Demography 38:147-59. https: //doi.org/10.1353/dem.2001.0011.

Fu, Vincent Kang. 2010. "Remarriage, Delayed Marriage, and Black/White Intermarriage, 1968-1995." Population Research and Policy Review 29:687-713. https ://doi .org/10 .1007/ s11113-009-9168-z.

Gordon, Milton Myron. 1964. Assimilation in American Life: The Role of Race, Religion and National Origins. Oxford, United Kingdom: Oxford University Press.

Gullickson, Aaron, and Florencia Torche. 2014. "Patterns of Racial and Educational Assortative Mating in Brazil." Demography 51:835-56. https://doi.org/10.1007/ s13524-014-0300-2.

Hamilton, Darrick, Arthur H. Goldsmith, and William Darity. 2009. "Shedding 'Light' on Marriage: The Influence of Skin Shade on Marriage for Black Females." Journal of Economic Behavior \& Organization 72:30-50. https : //doi .org/10.1016/j · jebo. 2009. 05.024.

Hanchard, Michael George. 1994. Orpheus and Power: The "Movimento Negro" of Rio de Janeiro and Sao Paulo, Brazil 1945-1988. Princeton, NJ: Princeton University Press. 
Harris, David R., and Hiromi Ono. 2005. “How Many Interracial Marriages Would There Be If All Groups Were of Equal Size in All Places? A New Look at National Estimates of Interracial Marriage." Social Science Research 34:236-51. https://doi .org/10.1016/j . ssresearch.2004.01.002.

Harris, Marvin, Josildeth Gomes Consorte, Joseph Lang, and Bryan Byrne. 1993. "Who Are the Whites?: Imposed Census Categories and the Racial Demography of Brazil." Social Forces 72:451-62. https://doi.org/10.1093/sf/72.2.451.

Hasenbalg, Carlos A. 1985. "Race and Socieconomic Inequalities in Brazil." Pp. 25-41 in Race, Class and Power in Brazil, edited by P. M. Fontaine. Los Angeles, CA: UCLA Center for Afro American Studies.

Heaton, Tim B., and Colter Mitchell. 2012. "Changing Intergroup Boundaries in Brazilian Marriages: 1991-2008." Journal of Comparative Family Studies 43:461-82. https : //doi .org/ $10.3138 / j c f s .43 .4 .461$.

Hordge-Freeman, Elisabeth. 2015. The Color of Love: Racial Features, Stigma, and Socialization in Black Brazilian Families. Austin, TX: The University of Texas Press.

Hughes, Michael, and Bradley R. Hertel. 1990. "The Significance of Color Remains: A Study of Life Chances, Mate Selection, and Ethnic Consciousness among Black Americans." Social Forces 68:1105-20. https://doi.org/10.1093/sf/68.4.1105.

Hunter, Margaret L. 2005. Race, Gender, and the Politics of Skin Tone. New York, NY: Routledge.

Jacobs, Jerry, and Teresa G. Labov. 2002. “Gender Differentials in Intermarriage among Sixteen Race and Ethnic Groups." Sociological Forum 17:621-46.

Kalmijn, Matthijs. 1991. "Shifting Boundaries: Trends in Religious and Educational Homogamy." American Sociological Review 56:786-800. https://doi .org/10.2307/2096256.

Kalmijn, Matthijs. 1993. “Trends in Black/White Intermarriage." Social Forces 72:119-46. https://doi.org/10.1093/sf/72.1.119.

Kalmijn, Matthijs. 1998. "Intermarriage and Homogamy: Causes, Patterns, Trends." Annual Review of Sociology 24:395-421. https ://doi .org/10.1146/annurev. soc . 24.1.395.

Kalmijn, Matthijs. 2012. “The Educational Gradient in Intermarriage: A Comparative Analysis of Immigrant Groups in the United States." Social Forces 91:453-76. https: //doi.org/10.1093/sf/sos128.

Keels, Micere, and Keshia Harris. 2014. "Intercultural Dating at Predominantly White Universities in the United States: The Maintenance and Crossing of Group Borders." Societies 4:363-79. https://doi.org/10.3390/soc4030363.

Loveman, Mara. 2014. National Colors: Racial Classification and the State in Latin America. Oxford, United Kingdom: Oxford University Press. https ://doi .org/10.1093/acprof : oso/9780199337354.001.0001.

Marteleto, Leticia J. 2012. "Educational Inequality by Race in Brazil, 1982-2007: Structural Changes and Shifts in Racial Classification." Demography 49:337-58. https : //doi .org/ 10.1007/s13524-011-0084-6.

Minnesota Population Center. 2017. “Integrated Public Use Microdata Series, International: Version 7.1." Retrieved March 18, 2019 (https://doi.org/10.18128/D020.V7.1). 
Nobles, Melissa. 2000. Shades of Citizenship: Race and the Census in Modern Politics. Stanford, CA: Stanford University Press.

Osuji, Chinyere. 2013. "Confronting Whitening in an Era of Black Consciousness: Racial Ideology and Black-White Interracial Marriages in Rio de Janeiro." Ethnic and Racial Studies 36:1490-506. https://doi.org/10.1080/01419870.2013.783926.

Park, Robert E. 1928. "The Bases of Race Prejudice." The Annals of the American Academy of Political and Social Science 140:11-20. https://doi.org/10.1177/000271622814000104.

Park, Robert Ezra, and Ernest Watson Burgess. 1921. Introduction to the Science of Sociology. Chicago, IL: University of Chicago Press.

Qian, Zhenchao. 1997. "Breaking the Racial Barriers: Variations in Interracial Marriage between 1980 and 1990." Demography 34:263-76. https: //doi .org/10.2307/2061704.

Qian, Zhenchao, and Daniel T. Lichter. 2007. "Social Boundaries and Marital Assimilation: Interpreting Trends in Racial and Ethnic Intermarriage." American Sociological Review 72:68-94. https://doi.org/10.1177/000312240707200104.

Rodríguez-García, Dan. 2015. "Introduction: Intermarriage and Integration Revisited: International Experiences and Cross-Disciplinary Approaches." The Annals of the American Academy of Political and Social Science 662:8-36. https://doi.org/10.1177/ 0002716215601397.

Rodríguez Ruiz, Pablo. 2004. "Raza y Estructuras Familiares en el Escenario Residencial Popular Urbano." Unpublished manuscript.

Roth, Wendy D. 2017. "Methodological Pitfalls of Measuring Race: International Comparisons and Repurposing of Statistical Categories." Ethnic and Racial Studies 40:2347-53. https://doi.org/10.1080/01419870.2017.1344276.

Sawyer, Mark Q. 2005. Racial Politics in Post-Revolutionary Cuba. Cambridge, United Kingdom: Cambridge University Press.

Schwartz, Christine R., and Robert D. Mare. 2012. "The Proximate Determinants of Educational Homogamy: The Effects of First Marriage, Marital Dissolution, Remarriage, and Educational Upgrading." Demography 49:629-50. https : //doi .org/10.1007/ s13524-012-0093-0.

Schwartzman, Luisa Farah. 2007. "Does Money Whiten? Intergenerational Changes in Racial Classification in Brazil." American Sociological Review 72:940-63. https://doi.org/10. $1177 / 000312240707200605$.

Sheriff, Robin E. 2001. Dreaming Equality: Color, Race, and Racism in Urban Brazil. New Brunswick, NJ: Rutgers University Press.

Skidmore, Thomas. 1974. Black into White: Race and Nationality in Brazilian Thought. New York, NY: Oxford University Press.

Sobek, Matt, and Sheela Kennedy. 2009. The Development of Family Interrelationship Variables for International Census Data. Minneapolis, MN: University of Minnesota.

Stephens, Thomas M. 1989. Dictionary of Latin American Racial and Ethnic Terminology. Gainesville, FL: University of Florida Press. 
Swidler, Ann. 1986. "Culture in Action: Symbols and Strategies." American Sociological Review 51:273-86. https://doi.org/10.2307/2095521.

Telles, Edward. 2004. Race in Another America: The Significance of Skin Color in Brazil. Princeton, NJ: Princeton University Press.

Telles, Edward, and Stanley Bailey. 2013. “Understanding Latin American Beliefs about Racial Inequality." American Journal of Sociology 118:1559-95. https ://doi .org/10.1086/ 670268.

Telles, Edward, René D. Flores, and Fernando Urrea-Giraldo. 2015. “Pigmentocracies: Educational Inequality, Skin Color and Census Ethnoracial Identification in Eight Latin American Countries." Research in Social Stratification and Mobility 40:39-58. https: //doi.org/10.1016/j.rssm.2015.02.002.

Telles, Edward, and Denia Garcia. 2013. "Mestizaje and Public Opinion in Latin America." Latin American Research Review 48:130-52. https : //doi .org/10.1353/lar.2013.0045.

Telles, Edward, and Tianna Paschel. 2014. “Who Is Black, White, or Mixed Race? How Skin Color, Status, and Nation Shape Racial Classification in Latin America." American Journal of Sociology 120:864-907. https : //doi .org/10.1086/679252.

Telles, Edward, and the Project of Ethnicity and Race in Latin America. 2014. Pigmentocracies: Ethnicity, Race, and Color in Latin America. Chapel Hill, NC: University of North Carolina Press.

Telles, Edward E., and Nelson Lim. 1998. “Does It Matter Who Answers the Race Question? Racial Classification and Income Inequality in Brazil." Demography 35:465-74. https : //doi.org/10.2307/3004014.

Wade, Peter. 1997. Race and Ethnicity in Latin America. Vol. 3. London, United Kingdom: Pluto Press.

Wade, Peter. 2005. “Rethinking Mestizaje: Ideology and Lived Experience." Journal of Latin American Studies 37:239-57.

Wimmer, Andreas. 2008. "The Making and Unmaking of Ethnic Boundaries: A Multilevel Process Theory." American Journal of Sociology 113:970-1022. https://doi .org/10.1086/ 522803.

Acknowledgments: The research conducted by Albert Esteve in this article has received funding from the following grants: ERC-2014-StG-637768 for the Equalize project and CRISFAM CSO2015-64713-R.

Edward Telles: Department of Sociology, University of California, Santa Barbara. E-mail: etelles@soc.ucsb.edu.

Albert Esteve: Centre d'Estudis Demogràfics, Universitat Autònoma de Barcelona. E-mail: aesteve@ced.uab.es. 